JOURNAL OF AWARENESS

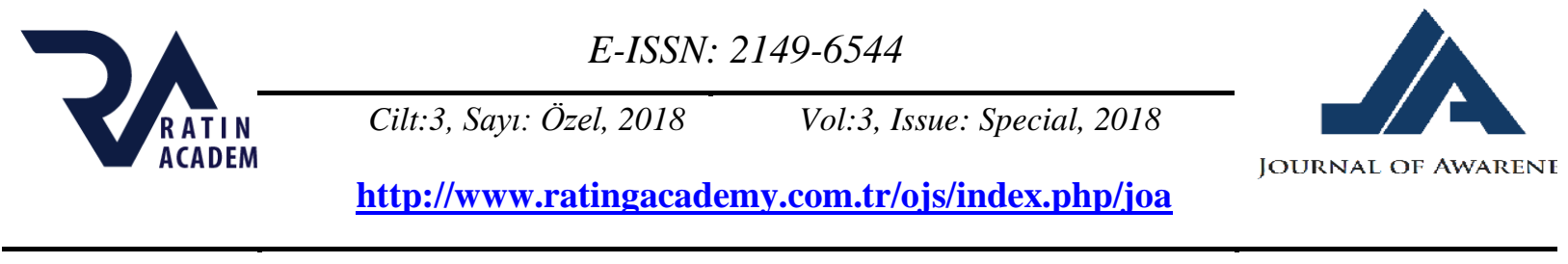

\title{
LINGUISTIC FUNCTIONS OF ADVERTISING IN SEMIOTIC COMMUNICATION*
}

Olger BRAME

Faculty of Education and Philology,

"Fan S. Noli" University, Korça-Albania E-mail: olgerbrame@yahoo.com

\begin{tabular}{l|l}
\hline ARTICLE INFO & \multicolumn{1}{c}{ ABSTRACT } \\
\hline $\begin{array}{l}\text { Keywords: } \\
\text { advertising, communication, } \\
\text { semiotics, language } \\
\text { functions }\end{array}$ & $\begin{array}{l}\text { The main objective of this paper is to provide definitions to understand how the } \\
\text { message transmitted in advertisements is interpreted } \\
\text { Semiotics is the science that studies signs and symbols. Semiotics deals with } \\
\text { symbols- texts and pictures- with their underlying meaning and the way they may } \\
\text { be interpreted. As a science, semiotics studies the signs of a language, which can } \\
\text { be verbal or nonverbal; it is the discipline that can be used to access different } \\
\text { DOI: } \\
\text { areas, including advertising. } \\
\text { One of the goals of semiotics is to convey and interpret the messages of } \\
\text { advertisements. It aims to study in depth the "advertising text" by reading between } \\
\text { the lines and to analyze the meaning structures, their syntactical and semantic } \\
\text { peculiarities. } \\
\text { Advertisements carry many hidden signs and meanings within them, because } \\
\text { advertising is communication. The messages involved in them transmit content, } \\
\text { which refers to different language communication functions. }\end{array}$ \\
\hline
\end{tabular}

Surveys about semiotics as a field of knowledge present a special and attractive interest at the same time, due to the specific focus of the discipline- " the study of "the life of signs within society." Different situations during the day provide us with various signs whom we interpret, which engage us in communication or which supply a model for our behavior.

Semiotics is an overall aspect of the cultural life and communication. According to semiotics, we can recognize the culture and the reality through the process of understanding. Umberto Eco, in his book "The theory of semiotics," states that "(...) semiotics is concerned with everything that can be taken as a sign. Since semiotics, "is concerned with everything that can be taken as a sign", Eco's definition of the sign can give us further insights into the delimitation of his semiotic field. He argues "since everything can be understood as a sign if and only if there exists a convention which allows it to stand for something else, and since some behavioral responses are not elicited by convention, stimuli cannot be regarded as signs" (Eco, 1976). Semiotics is the science that studies the verbal and non-verbal signs involved in a language. It is a discipline that can be used to access various fields, including advertising. In its simplest sense, the word "advertising" means "attracting attention to something", or "informing someone about something". (Dyer, 1982: 2).

At the root of the word 'advertisement' is the Latin verb 'advertere',meaning 'to turn towards" or "to consider". It is certain that the visual and commercial verbal messages, which 
are part of the advertising, are intended to attract attention and to produce some responses from the receiver, by making it compelling and practically impossible to escape from (Schement, 2002: 10). Advertising is defined as "a massive aesthetic and ideological tool, a source that modifies the way we look at things, makes us discover beauty, have fun and dream (...)" (Volli, 2005). From a relatively narrow point of view of human communication, semiotics, or semiology, is, in its deep roots, the study of signs and symbols that people use to represent the way these signs and symbols are interpreted in the various world contexts and the way people use them in reality and particular social experiences. Advertising, as a form of language communication, has a specific language structure. It expresses the message with a given languistic form. From a semiotic perspective, the advertisement contains more than one sign. It consists of an element of language, which is organized by the respective sign or from the aspect of the advertising material that may be a painting, a photo, an illustration, etc.

According to Eco, advertising is a special case of "comforting" communication, present in mass communication; a communication that offers to its recipients, exactly what they expect from it, by enjoying, in seemingly new messages, what is already known. (Marrone, 2008: 155156). The linguistic and semiological view of advertising, supported by the notions of rhetorics, overcomes the idea of communication as a commercial conviction. In the advertising message, nothing acts at an unconscious level for a client (in the sence that the later is a totally passive consumer). On the contrary, the diversity of semantic levels of the message is meant to revive the range of individual and social experiences. Like the word, the image itself has two levels of reading compehension: the first is that of the advertiser- the connotative- and the second is the visual -associated with the denotative aspect. This refers to the fact that the image in the advertisement appears as a representation of something else. (Felice, 2009). Some of the advertisements found in the Albanian media promote wordplays, jargon of youth language, words, sentences and other constructions that justify what was mentioned above- using different tools in function of language communication fulfillment:

Birra Tirana - "Me kuqalashen, për kuqalashët..." (Tirana Beer-"With the reddish, for the redheads)

Eurosig - "Ti je Ai...Ti je Shqiptar...Ti je e Ardhmja",( Eurosig - "You are the One ... You Are Albanian ... You Are the Future";

Birra Peja - "Gëzuar ty që beson,'( Peja Beer - "Cheers to you, the believer)

Coca Cola - "Taste the feeling";

Vodafone -E ardhmja është emocionuese. Be Happy; (The future is exciting. Be HappyVodafone)

Vodafone- "Fuqia për të shkuar përtej të zakonshmes",4(Vodafone - "The power to go beyond the ordinary.")

Korça - Edhe sot më e mira, ${ }^{5}$ ( Korça - Still the best)

Super Smart Phone për kujtime Super; (Super Smart Phone for Super Memory)

Kredi personale? Mos jeto me idenë, realizoje! ${ }^{6}$ (Personal loan? Do not live with the idea, make it a reality!)

\footnotetext{
${ }^{1}$ Advertising of Albanian Beer in red bottle packaging

2 Advertising for an Insurance Company in Albania

${ }^{3}$ Advertising of Kosovo Beer

${ }^{4}$ Advertising of Vodafone phone company in Albania

${ }^{5}$ Advertising of First Albanian Beer

${ }^{6}$ Advertising of Raiffeisen Bank in Albania
} 
Credins Bank-Ne flasim gjuhën tuaj: ${ }^{7}$ (Credins Bank - We speak your language;) etc.

Since it is an important part of mass communication, like the newspapers, the radio, the television, etc., advertising focuses on the way the message passes from the provider to the receiver. From this point of view, advertising means communication. The messages that it conveys transmits content, which may refer to language communication functions. It is known that the communication process is related to important factors that include the one who transmits something, to whom it is transmited, through what means, what is the broadcast code, etc.

Communication is the process that is carried out between at least two sides - the addresser (the conveyer or the writer) and the addressee (the receiver - the listener or the reader). The encoded meaning (the information) is transmitted through a communication channel between them. Each communication is realized in a given context or situation. If the Jacobson's model of communication is used as a starting point, the analysis helps to understand elements of communication/ its core components. The advertising language is various, because it is or should be understood by most consumers.

One of the main objectives of the advertising language is obviously to establish a rapid and effective communication, through a message of limited length (concise) and through the repetition of the message itself to make sure that it is stored in the reader's mind. In order to fully supply connotative and denatative meanings, advertising makes use of a wide range of lingusitic sources, varied syntactic forms, different tools, and rhetorics.

According to Peninou, the advertising world best exploits all the possibilities and ways of communication (Péninou, 1972). Language has a twofold function: it plays an important communication role and imposes a given image to the people. This is usually done through a stereotype provided by models, for example, the image of person who looks both successful and happy. That is why advertisers should choose carefully the words of the advertisements in order to present the object of desire in a proper and efficient way (Goddard, 2005). Denotation and connotation, of what is displayed or shown in advertising, is very important in understanding the meaning of advertising. Denotation and connotation are the terms that describe the relationship between the signified and the signifier in semiotics. The meaning itself includes both denotation and connotation.

The relationship between the sign and the object, the signified and the signifier is complex. It may be straightforward and determined, but it may also be unclear and therefore requires further explanations. The difference between these two forms of relationship is conveyed through the denotation sign, as it is directly linked to the focus object. The sign, in this case, is called denotative or indicative. The relationship is extensive, when it refers to multiple meanings of the sign. In this case, it is defined as connotation and the sign is connotative. The connotative meaning conveys a general message about the meaning of the product that the advertisement creates by using the image. Advertising works by showing the addressee an easily readable sign and by placing it next to another sign that is potentially unclear (Barthes, 1972/2001).

According to Volli (2005), the denotation can be called a "strong nucleus", which is surrounded by connotation that is made up of varied and sometimes complex meanings. Connotation and denotation are often described in terms of levels of representation or levels of meaning. In this regard, Barthes tried to show how cultural construction of the meaning of advertising in sign production is hidden. According to him, advertising uses tricks of imaginary deals to search for the meanings of their products. In this sense, Barthes emphasizes that

\footnotetext{
${ }^{7}$ Advertising of Credins Bank in Albania
} 
advertising offers the readers what they themselves try to be or to reach, using connotative associations (Richards at al 2013).

Let's try to illustrate it with an example:

Fig.1.Denotation and connotation of advertising

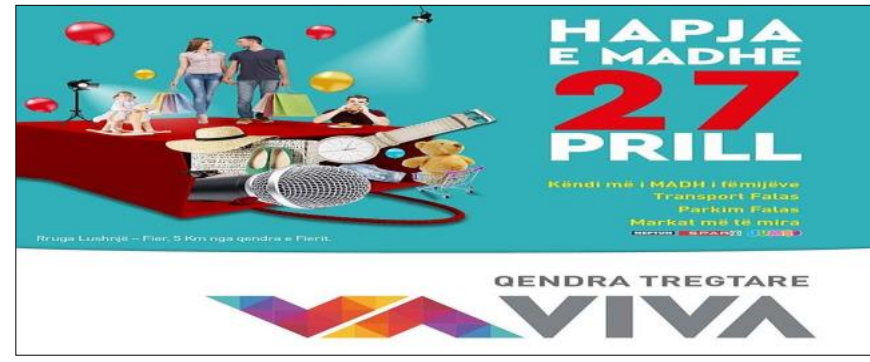

Photo is taken by VIVA@qendra.tregtare.viva

The question we will try to answer is: What does the image of the advertisement show and what is immediately apparent, before we read between the lines? (Rayner and Wall, 2009: 40-43).

- Denotation consists of a young, smiling, happy man, holding shopping bags on both hands and a child who enjoys playing.

- There are colored balloon in the background to show celebrations.

- The addresser strongly invites others to become part of this holiday because they are much likely to find facilities for children, parking, transportation and the best brands.

- The addressee is tempted by what he/she sees and is likely to think that the couple is happy after the purchases- already made or to be made; however the later can not be confirmed by the image itself. We can not really see the shopping mall being advertised; we do not know whether this will really happen at the time of the "Great Opening": as addressees we just suppose, based on what is written and the visual offers of the advertisement.

- What really catches the addressee's eye on the site, is the slogan "Great Opening".

As for the connotation, accroding to Rayner and Wall (2009) the reader can add to this information, by engaging himself in higher efforts of identifying what the signs mean to his background cultural experiences.

The example provided above:

- It is a picture of a young couple who like to make purchases, they like fashion, they are happy and they have fun this kind of activity.

- They seem to be rich and even have enough time to enjoy each-other's purchases and entertain their children.

- They have enough money to make purchases in shopping malls where are the best clothing brands, which should be more expensive than the usual clothing market.

However, there is a strict separation between denotation and connotation. Barthes came to the conclusion that "denotation is not the first meaning, but pretends to be so; under this illusion, it is ultimately no more than the last of the connotations. Connotation, in short, produces the illusion of denotation, the illusion of language as transparent and of the signifier and the signified as being identical. Thus denotation is just another connotation" (Barthes, 2002: 9). 
Eco (1976) also emphasizes how denotation and connotation can be considered as cultural units. According to him, the typology of connotation varies as a final meaning, a continuation of meaning, as an ideological, semantic, stylistic, global connotation.

Another important aspect of advertising as a semiotic element of communication is related to the fulfillment of linguistic communication functions associated with the name of Roman Jakobson. Jakobson's model analysis of communication shows that it is a characteristic analysis of semiotic rather than a linguistic origin, as he himself believes (Eco, 1987: 109-123). In analyzing the language of advertising, the six language functions identified by Roman Jakobson have to be taken into consideration.

Figure 2. Jakobson's six functions of language

\begin{tabular}{|c|c|c|}
\hline & $\begin{array}{c}\text { CONTEXT } \\
\text { (referential) } \\
\text { MESSAGE } \\
\text { (poetic) }\end{array}$ & \\
\hline $\begin{array}{l}\text { ADDRESSER } \\
\text { (emotive) }\end{array}$ & $\begin{array}{l}\text { CONTACT } \\
\text { (phatic) } \\
\text { CODE } \\
\text { (metalingual) }\end{array}$ & $\begin{array}{l}\text { ADDRESSEE } \\
\text { (conative) }\end{array}$ \\
\hline
\end{tabular}

Adapted from "Linguistic Antropology: Cambridge Texbooks in Linguistics" by A. Duranti, p. 284. Cambridge University Press, 1997

Roman Jakobson defined six language functions (or communication functions), according to which an effective act of verbal communication can be described. Each of these functions has an associated factor. Although the rule may be determined from the dominant function of each message, it is not the only function of these messages; it comes with other, more or less distinct functions. Jakobson's communication system can be summarized in the table below.

Table 1. Jakobson's functions of communication

\begin{tabular}{|c|c|c|c|}
\hline $\begin{array}{l}\text { Target } \\
\text { factor }\end{array}$ & $\begin{array}{l}\text { Source } \\
\text { factor }\end{array}$ & $\begin{array}{l}\text { Language } \\
\text { function }\end{array}$ & Examples \\
\hline Context & message & Referential & $\begin{array}{l}\text { The message serves to } \\
\text { present the reality }\end{array}$ \\
\hline Addresser & message & Emotive & $\begin{array}{l}\text { The message serves to } \\
\text { express feelings of the } \\
\text { addresser }\end{array}$ \\
\hline Addressee & message & Conative & $\begin{array}{l}\text { The message serves to } \\
\text { act upon the addressee }\end{array}$ \\
\hline Contact & message & Phatic & $\begin{array}{l}\text { The message serves to } \\
\text { provide the contact }\end{array}$ \\
\hline Code & message & Metalingual & $\begin{array}{l}\text { The message explains } \\
\text { the elements of the code }\end{array}$ \\
\hline Message & message & Poetic & $\begin{array}{c}\text { The message is } \\
\text { organized based on its form }\end{array}$ \\
\hline
\end{tabular}

Adapted from: "Shkencat e komunikimit-Teori dhe arritje" by B. Oliver p. 93, Botime Papirus,Tiranë, 2015

These functions are associated with the components of the communication act and on the other hand, do not exclude each other, but also often overlap. Three of these functions relate 
to the content and can be realized with several types of advertisements. If we combine these functions with advertising as a semiotic communication element, some analogy can be drawn.

Let's illustrate with some examples.

The referential function, according to Jacobson, relates to the referent and the context of communication and it is used as a means of providing information to the referent, ie. information about something in the world around us. The referent can be replaced by the socalled "referential advertisement". According to this concept, presented by Laufer and Paradeise (1988), this type of advertisement simply informs; it presents the content of a message without including what it gives or receives (these are ads that do not need excess, that have spared words, mostly a picture and a short text).

Korca Beer, even today the best...(Fig.3.1)

Korca Beer -the first Albanian Beer, since 1928 (Fig.3.2.)

So, referential ads, just as the referential function, are used as a tool to give us information about the referent.

Fig.3. The "Referential advertising "

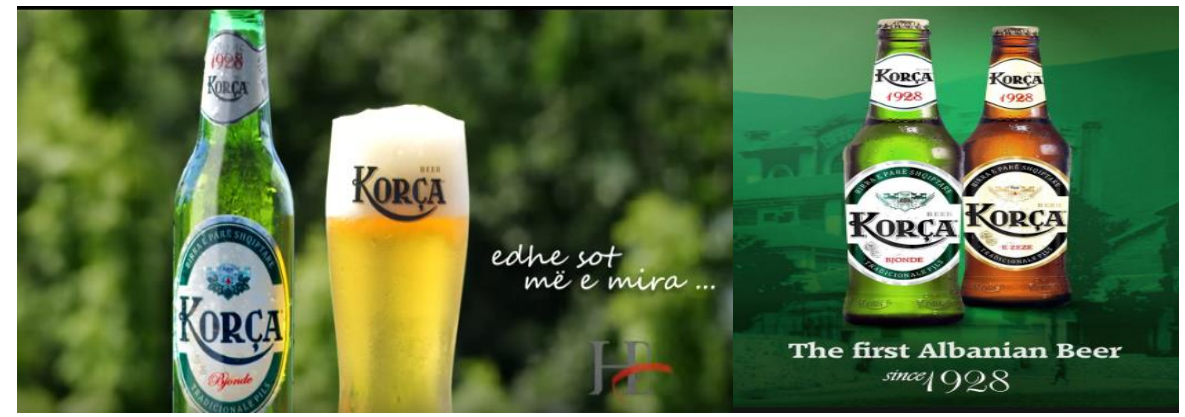

Photo is taken from: https://birrakorca.com.al

The metalingual function is related to the difference between two uses of language: when the language is used to talk about objects and when it is used to talk about itself- on what is known as meta-language (Memushaj, 2006: 20-24).

"Meta-language" advertising deals with subjects and calls for relevant knowledge, using a relevant terminology, which is needed to be translated and understood by ordinary people. Thus, "meta-language" advertising relates to the clarification of a sign with other signs that reveal the meaning of the first sign in the advertisement.

Fig.4-5. The "Meta-language" advertising

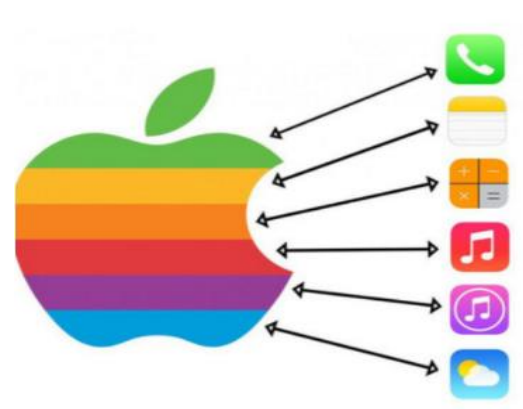

Photo is taken from: https://www.pinterest.com/pin/ saved by Bill Eitel

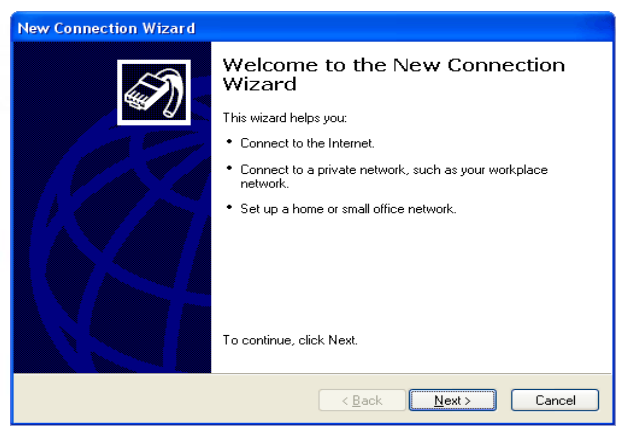

Photo is taken from: Windows XP Networking Guide: conniq.com 
The poetic function emphasizes the message itself. According to this function, a proper linguistic analysis is required. "Poetic" advertisment relates to an added value of the message meaning through various stylistic features. The language of the advertisements mainly uses the poetic function. For example, if we say: Korca Beer in a bottle, it can take an advertising farm like: Korca in a bottle; or in the variant: Korça, already in can. (Korca Beer already in the packaging of cans), or Korça blonde cans and Korça black cans (Korça-kanaçe bionde dhe Korça kanaçe e zezë)

Fig.6. The "Poetic" advertising

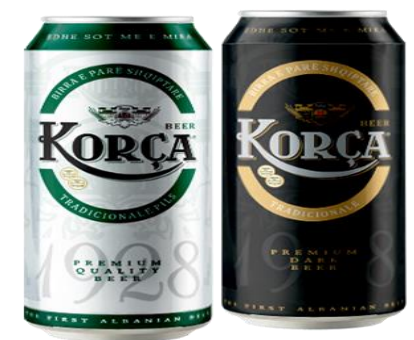

Photo is taken from: https://birrakorca.com.al

The expressive-emotional function, relates to the message transmitter, and the language in this function serves to reveal the feelings and attitudes of the speaker about the meaning it conveys. In addition to delivering the product qualities, the "expressive-emotional" advertising provides qualities and features on how this product is produced- and attaches to it the feelings of the message conveyer. This type of advertisement is not a simple mirror of the reality; it is a subjective interpretation of the real fact.

Fig.7. The "expressive-emotional"advertisement

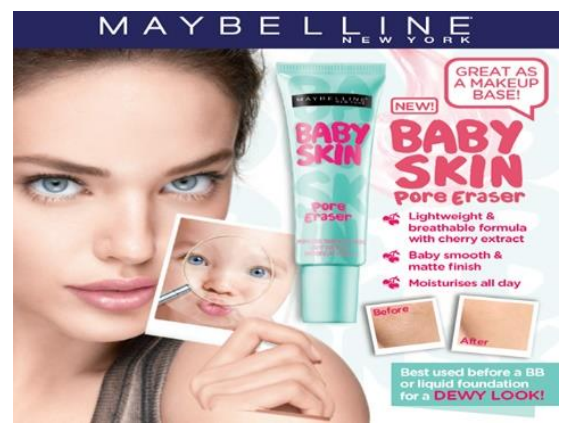

Photo is taken from: https://www.maybelline.com/

The conative function, which is related to the receiver of the message. Through language, it aims to create emotional feelings and aims to impress him/her. In the advertising field, this function is very important because it is directly related to the extend the receiver in convinced by the message. The "conative" advertising enables an addressee's involvement both through the recognition of his personality and character, as well as through his/her behavior or language. (Habib and Rensonnet, 1975).

If we refer to the following two examples: the first, "1000 life insurance policies, from SIGAL" is directly related to the extend the receiver in convinced by this message. Also in the second example: "Home Decoration Loan. Apply Now! Add Value to Your Home!, its purpose relates to encouraging the recipient as soon as it reads this sentence. So it seems that we are dealing with an imperative or evocative function. 
Fig. 8-9. The "Conative" advertising

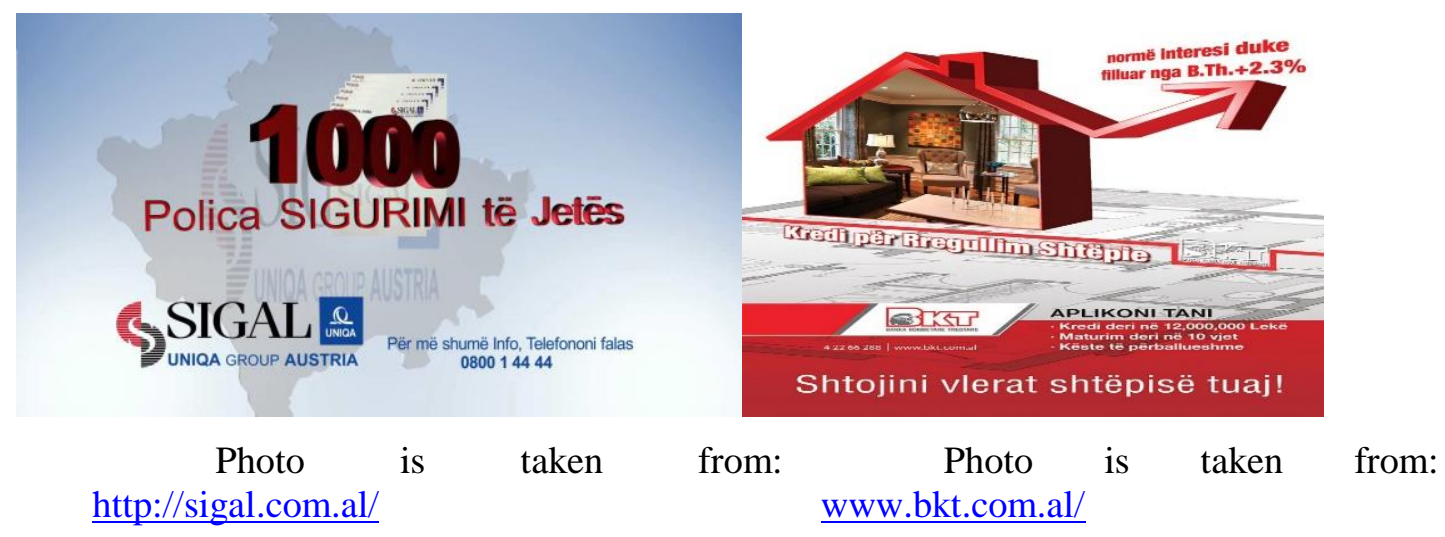

The phatic function is intended to keep the communication channel operational and to ensure its existance between the message sender and the receiver. The "phatic" advertisement delivers such messages that encourage the reader to be creative, to imagine, or to become a potential consumer of this product. Only a phatic approach could encourage such behavior.

Fig.10. The "phatic" advertising

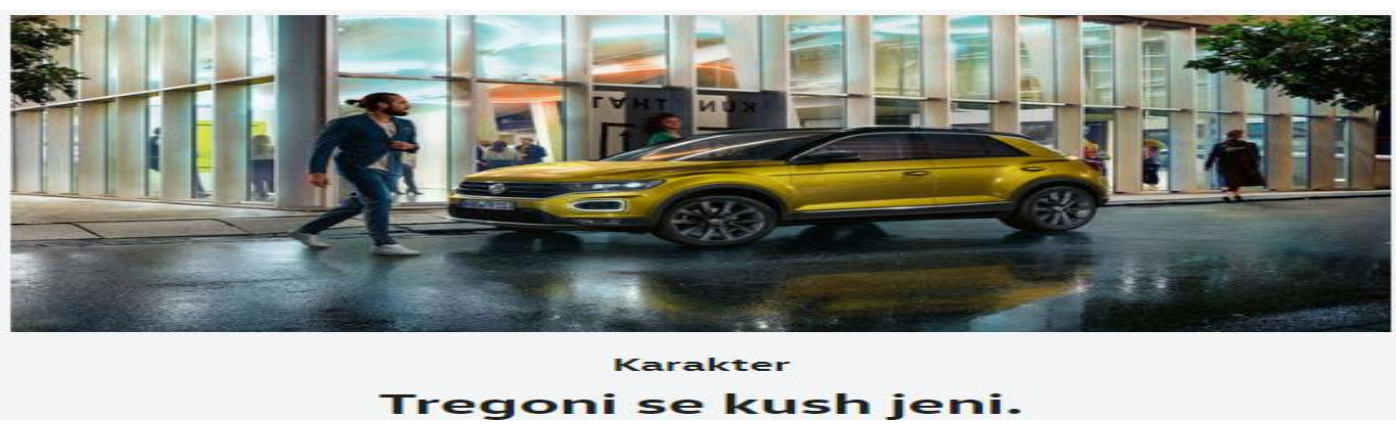

Photo is taken from: https://www.volkswagen.al/

\section{CONCLUSIONS}

Advertising is part of mass communication, and can enjoy the status of a special form of communication due to the tools it uses, to the value it provides, to the structure and content it reflects, as well as to the goals it accomplishes. Advertisements maintain many hidden signs and meanings, such as: marks, logos, colors, trademarks etc. To understand the meaning of the signs, three essential elements are identified.

The first element is the "formal structure" of advertisements (the establishment of a relationship between a sign to another based on their place in advertisements). Secondly, consumers are able to "read" the connotation of these signs; and thirdly, there is always a connotative meaning, which already exists in consumer culture (Williamson, 1978).

Observed by the parameters of the communication theory (according to Jakobson's diagram), all language functions find expression in advertising communication. Semiotic theories and methods can be used to identify trends in cultural terms, to understand how the behaviors and attitudes of consumers and advertising can meet these needs by improving the users' communication.

The advertising world takes care of the best use of all the possibilities and ways of communication, which in this case is the language. It avoids the normative use of language, uses cuts, unusual syntactic constructions and borrowings, especially from English. Language 
resources are used by advertisers to raise attention, desire and to impact memory. It addresses formal and regular patterns such as repetition of sounds, ambiguous words, idiomatic expressions, and so on. In many cases, what "hits" more in advertising messages is the language form rather than the name of production itself. 


\section{BIBLIOGRAPHY}

BARTHES, ROLAND. (1972/2001) Mythologies The Noonday Press - New York Farrar, Straus \& Giroux, Thirty -seventh printing edition, New York: Hill \& Wang, A Division of Farrar, Straus and Giroux.

Barthes, ROLAND. (2002) S/Z, United Kingdom: Blackwell.

DYER, GILLIAN. (1982) Advertisingsign as communication (Studies in culture and communication), London: Taylor \& Francis e-Library.

ECO, UMBERTO. (1976) A Theory of Semiotics (Advances in semiotics), Blumington: Indiana University Press.

ECO, UMBERTO. (1987) The influence of Roman Jacobson on the Development of Semiotics', Classics of Semiotics-TOPICS IN CONTEMPORARY SEMIOTICS , $1^{\text {st }}$ edition, New York: Springer Science+Business Media.

FELICE, D. (2009) Analisi semiotica della pubblicità, 14 Dec, [Online], Available: http://www.comunitazione.it [1 Dec 2018].

GODDARD, ANGELA.(2005) The Language of Advertising, $2^{\text {nd }}$ edition, London: Routledge.

HABIB, JACQUES and RENSONNET, JEAN-PHILIPPE. (1975) Le marketing du nouveau produit : stratégie de croissance, recherche et sélection de concepts, positionnement, tests et plans de lancement, Paris: Dunod.

MARRONE, GIANFRANCO. (2008) Trupat shoqërorë, Tiranë: Botimet Dudaj.

MEMUSHAJ, RAMI. (2006) Gjuhësi e përgjithshme, Botimi i tretë edition, Tiranë: Botimet Toena.

PÉNINOU, GEORGES.(1972) Intelligence de la publicité: etudié sémiotique, $1^{\text {st }}$ edition, Paris: Broché.

RAYNER, PHILIP and WALL, PETER. (2009) AS media studies: the essential introduction, Third edition, London: Routledge.

RICHARDS, BARRY. MACRURY, IAIN. BOTTERILL, JACKIE. (2013) The Dynamics of Advertising, London: Routledge.

Schement, JORGE REINA. (2002) Encyclopedia of Communication and Information , $1^{\text {st }}$ edition, New York: Macmillan Library.

VOLLI, UGO. (2005) Manuale di semiotica, $14^{\text {th }}$ edition, Roma: GLF.

Williamson, JUDITH. (1978) Decoding Advertisements: Ideology and Meaning in Advertising, London: Boyars Publishers, Ltd., Marion.

DURANTI, ALESSANDRO (1997) Linguistic anthropology- Cambridge Textbooks in Linguistics, Cambridge: Cambridge University Press.

PARADEISE, CATHERINE. and LAUFER, ROMAIN. (1988). Stock Image Marketing Democracy: Public Opinion and Media Formation in Democratic Societies, Published by Transaction Publishers,

OLLIVIER, BRUNO.(2015) Shkencat e komunikimit-Teori dhe arritje,Tiranë, Botime Papirus. 